\title{
THE ANTECEDENTS OF RECOGNIZE THE VALUE IN THE ABSORPTIVE CAPACITY
}

\author{
DOUGLAS FILENGA ${ }^{1}$ \\ (iD) https://orcid.org/0000-0003-1809-5821 \\ OTÁVIO P. SANCHEZ \\ (iD) https://orcid.org/0000-0002-5708-9080
}

To cite this paper: Filenga, D., \& Sanchez, O. P. (2020). The antecedents of recognize the value in the absorptive capacity. Revista de Administração Mackenzie, 21 (4), 1-24. doi:10.1590/1678-6971/ eRAMR200069

Submission: Apr. 10, 2019. Acceptance: Oct. 10, 2019.

1 Federal Institute of Education, Science and Technology of São Paulo (IFSP), Suzano, SP, Brazil.

2 Getulio Vargas Foundation (FGV), São Paulo, SP, Brazil.

\section{(c) $\mathrm{BY}$}




\section{ABSTRACT}

Purpose: The ability of individuals to recognize the value of external, corporate-applicable information is critical to organizational absorptive capacity. This study aims to define and operationalize the recognize the value construct, identify its antecedents and predictive power.

Originality/value: It analyzes how this construct occurs at the level of the individual, workgroups and processes, besides indicating its relationship with the other predictors present in the literature. The theoretical bases can be classified by Cohen and Levinthal (1990) and Zahra and George (2002). The first one considers absorptive capacity as a stock of knowledge, the second one, as dynamic capacity.

Design/methodology/approach: We adopt the Structural Equation Modeling technique to test a variance model, with four predictors of general recognize the value. We use a non-probabilistic sample consisting of 283 individuals who answered an electronic questionnaire.

Findings: The results are satisfactory, as the model shows a $40 \%$ prediction power of how recognize the value occurs. The work processes were found to show higher predictive power $(\beta=0.417)$, meaning that that processes of recognize the value are enablers of the organizational recognize the value of new information. The other hypotheses were also supported, but with comparatively minor effects. The study is limited to the identification and analysis of the effects of predictors and does not contemplate its consequences, whose research is suggested.

\section{KEYWORDS}

Absorptive capacity. Recognize the value. Social integration mechanisms. Appropriation regimes. Relationship power. 


\section{INTRODUCTION}

As organizations experience a more competitive environment, the absorptive capacity (AC) becomes particularly important, because it allows for shorter development cycles, increased innovation and improved market reactivity (Lane, Koka, \& Pathak, 2006). AC refers to the ability of the organization to identify valuable external knowledge, assimilate that knowledge and apply it internally in order to guide its competitive actions (Cohen \& Levinthal, 1990). However, the ability to develop and maintain such organizational skills is crucial to organizational survival, because AC can refocus the strategic actions of organizations (Zahra \& George, 2002).

Especially relevant to AC, recognize the value is a construct that addresses the organization's ability to identify the value of information outside the organization, so that it can be harnessed within the internal organizational environment (Lane et al., 2006). Although the literature usually identifies the AC by associating it with its effects on the organizational level, multiple levels of analysis are necessarily involved in order to achieve its results. For example, recognize the value cannot be considered a skill at the individual level alone, nor simply the sum of the multiple individuals in the organization, but it depends on a mosaic of matching organizational and individual capabilities (Cohen \& Levinthal, 1990, p. 133).

While recognize the value is particularly important in the context of identifying useful external knowledge applicable to the organization, little is known about the elements that stimulate such ability to be effective. Multiple studies have related it to process competence (Engelman, Fracasso, Schmidt, \& Zen, 2017) or technology (Roberts, Galluch, Dinger, \& Grover, 2012), but its training structure remains little explored. Thus, the motivation for this work is to empirically analyze the antecedents of recognize the value in the context of AC, taking as reference its institutional aspects, as is the case of the social integration mechanisms (SIM) adopted by the companies, in addition to the regime of appropriability and relationship power in different organizational contexts.

Investigating this research model provides four specific contributions. The first of these stems from the fact that the model is investigated by variance rather than procedural models adopted in part of the literature (Roberts et al., 2012). The second refers to the conceptual redefinition of the studied variables. The third is about the relevance of analyzing the hierarchical level of the components involved in recognize the value. The fourth is related to 
the readjustment and positioning of variables originally conceived as moderating and predicting.

This study consists of five parts. It starts by reviewing the literature with the described gap and the presentation of the hypotheses. Following, the research model and the treatment of the data. Then, the methodology and the results and analysis. It concludes with the final considerations.

\section{LITERATURE REVIEW}

This section discusses the review of available literature on AC, focusing on investigating the theoretical and empirical gaps between the relationship of regimes of appropriability, SIM, and relationship power as direct predictors of recognize the value.

\subsection{Recognize the value}

Recognize the value is defined as the ability by which individuals, groups, or processes identify external information, new or available, to apply it in the internal environment of the organization. Such a definition is supported by the coverage of the individual, group and work process levels, and a significant portion of attributes inherent to the theme, as proposed in the AC literature (Duchek, 2013; Nonaka \& Takeuchi, 1995; Cockburn \& Henderson, 1998; Zahra \& George, 2002; Cohen \& Levinthal, 1989; Antonello, 2007).

The positioning and even the treatment given to recognize the value allows the categorization of two-pronged AC studies: 1. as an Acquisition under a four-dimensional internal model, according to Zahra and George (2002); and 2. as one of three dimensions, according to Cohen and Levinthal (1990). In common, both seminal models present their analyzes of procedural form, that is, a sequence of steps, without which one does not happen without the previous one. For example, the statement that AC stems from investments in research and development (R\&D) (Cohen \& Levinthal, 1989; Martinez-Noya, Garcia-Canal, \& Guillen, 2013; Camisón \& Forés, 2010; Schweisfurth \& Raasch, 2018). Such a statement can be found in the literature in different contexts, such as in a partner company (Schleimer \& Pedersen, 2013) and acquisition processes (Yildiz, Fey, \& Zou, 2018). However, in this study, the investigation took place in a variance model, given the lack of these studies for the direct antecedents of recognize the value (Duchek, 2013; Bolívar-Ramos, García-Morales, \& Martín-Rojas, 2013). 
Despite these aspects, there was a predominance of studies on treating recognize the value from the perspective of Cohen and Levinthal (1990). However, the changes proposed by Zahra and George (2002) contesting the "knowledge stock" as opposed to dynamic capacity, as proposed by Engelman et al. (2017), give less importance to the variable. Therefore, Todorova and Durisin (2007) represent it differently, rescuing the seminal propositions, while maintaining the acquisition dimension and the other sub-dimensions of Zahra and George (2002) in the composition of AC.

The importance of recognize the value can also be noted by different focuses of study, for example, as being linked to an organization's prior and available knowledge base (Lane \& Lubatkin, 1998), when allied with research institutions (Cockburn \& Henderson, 1998), and even in the exchange of knowledge (Nahapiet \& Ghoshal, 1998), albeit due to collective returns or interpretations of reality (Roberts et al., 2012; Bosch, Volberda, $\&$ Boer, 1999). Despite the relevance of this construct in the composition of the AC functionality (Bosch, Wiik, \& Volberda, 2003), no conceptual redefinition was noted. Previously, studies have relied on the definitions of seminal articles, although their positioning has varied, such as when they are needed (Liyanage \& Barnard, 2003). Exception for Daghfous (2004), who treated the "understand" dimension as the ability to recognize the value, and acquire external knowledge that is critical to the company's operations and also to Harrington and Guimaraes (2005), who treated it as being an ability of the company organization, present in the diversity of organizational members.

\subsection{Processes of recognize the value}

The definition and conceptual basis of this variable follow that of general recognize the value; that is, the variable that represents the capacity by which individuals, groups, or processes identify external information, new or available, aiming the application in the internal environment, therefore, it is the level of analysis. Once individuals and groups can recognize the value of valuable information to bring to the company, they organize, systematize and contribute, so that, in work processes, they can recognize the value of information that can be harnessed within the company. In other words, it is the ability to recognize the value of new or already available external information to bring to the company, through work processes, the company's ability to appropriate these conditions through general recognize the value. It is also proposed that this effect becomes even more relevant 
when studied in conjunction with other predictor variables, such as SIM, such as meetings, formal and informal meetings, and other socialization and engagement techniques. These are the theoretical formulations to present the investigation of the first hypothesis of this study.

- $\mathrm{H}_{1}$ : There is a positive association between the processes of recognize the value and general recognize the value.

\subsection{Social integration mechanisms}

The relevance of this construct is already noted in the seminal study by Cohen and Levinthal (1990). Such mechanisms may influence the time lags to integrate or replace individuals, particularly those most concerned with innovation. Such activities condition their success to social factors, not only technical ones, as Lane and Lubatkin (1998) argue, besides making the original organization less imitable, increasing the strategic value of its members. SIM are valuable organizational resources, as well as social integration itself. Tortoriello (2015) argues that if there are failures within SIM, individually, each one has to overcome these failures on their own, as a condition to obtaining AC. The more appropriate the SIM are, the greater will be the performance in recognize the value of external information that should be used in the internal environment. SIM must be effective to support the process of generating innovation. SIM are, for Zahra and George (2002), tools that organizations have to reduce the barriers between the internal dimension of AC, named assimilation, and the other dimension, called transformation, whose argument is also corroborated by Daghfous (2004). Also according to the authors, AC is composed of two stages: the potential one and the realized one. The former brings together the acquisition and assimilation dimensions, sequencially. The latter, also consecutively, brings together transformation and exploitation. The transformation dimension is the most contested by Todorova and Durisin (2007), because they consider it fundamental to reconnect the two stages and maintain the seminal postulates. In the considerations of Camerer and Vepsalainen (1988), these mechanisms can collaborate and develop an organizational socialization capacity and refer to a shared value, as well as a collective interpretation of reality, and they allow the existence of AC, broadly specifying the rules of knowledge. It is in this sense that Magni, Paolino, Capetta, and Proserpio (2013) state that the working group can be considered a SIM, because when individuals have high levels of AC, their learning level tends to decrease, but by the way the working group interacts with it via learning processes in the 
group, this process can be reversed and result in more effective learning at the individual level, i.e., group learning has positive impacts on the learning of those with individual absorptive overcapacity. For Hotho, BeckerRitterspach, and Saka-Helmhout (2012), social interaction is a prerequisite for controlled AC, as it allows employees to participate in the transformation of new knowledge into the local context. For example, organizational conditions in a subsidiary may affect the subsidiary's AC by facilitating or hindering interaction patterns. These findings contribute to AC by demonstrating the scale and scope of social interaction as a fundamental link between the individual and organizational level in AC, involving knowledge that is recognized as the organization's primary resource, and that requires combined effort and a high degree of experience.

Thus, the literature review has shown that mechanisms promote social integration and, in turn, break the inertia of socialization. It is not enough that there is a respectful environment favorable to working conditions; there must be incentives that result in integration. Roberts et al. (2012) speak of synergy between individuals and not merely the sum of the parts. Todorova and Durisin (2007) assert that these mechanisms are critical contingencies for $\mathrm{AC}$ and that the moderating influence of social integration on $\mathrm{AC}$, as a whole and not on parts as Zahra and George (2002) take it into consideration, is likely to affect all components of $\mathrm{AC}$ and have a positive or a negative effect, depending on specific contingencies. The mechanisms influence social interactions and can compromise the knowledge processes that occur among the members of the organization (Vega-Jurado et al., 2008; Yam, Guan, Pun, \& Tam, 2004), including inter-organizationally (Lane \& Lubatkin, 1998), by the image that the organization conveys to the market (Camerer \& Vepsalainen, 1988), which highlights relatively different aspects of competitors, all from social integration that, for Popadiuk (2012), are resources that must be managed in order to provide the organization with a competitive performance that is preferably superior to the competition.

- $\mathrm{H}_{2}$ : Social integration mechanisms are positively associated with general recognize the value.

\subsection{Regimes of appropriability}

Regimes of appropriability are market barriers imposed on organizations to control or protect valuable information. The regimes of appropriability dimension stem from the low intellectual effectiveness of the company and 
inhibit the returns of innovation (Teece, 1986). For example, for Cohen and Levinthal (1990), the regimes of appropriability establish acts as a moderating variable between sources of knowledge and prior knowledge in the context of $\mathrm{AC}$, that is, from the beginning of what will define whether the organization will be innovative. In the models considered here, the position of this construct is controversial. For Zahra and George (2002), it is located between the AC and the organization's competitive advantage. Todorova and Durusin (2007) position the construct not only after AC but also before it, characterizing differences regarding access to information from others and information already available. For Lane and Lubatkin (1998), regimes of appropriability refer to the ability of companies to capture the profits created by their innovative activities, characterizing internal protection within the same sector. Thus, if a company in the industry can routinely capture most of the profits from its innovations, the appropriateness of competitors is low because they will take little advantage of the valuable information the innovative company has. If, however, this innovative knowledge it creates tends to spread to rivals who can also capitalize on it, the appropriateness of competitors is high. The overflowing level of an industry, in turn, is a function of patent strength, the ability to keep innovations secret, and the value of pioneering advantages. This spill is called by Cohen and Levinthal (1990) spillovers when they state that a high degree of regimes of appropriability reflects a low level of spillover, as these barriers determine incentives to invest in AC and moderate their antecedents. Thus, the effect of the regimes of appropriability on AC is negative, that is, AC decreases in the face of high levels of regimes of appropriability, as they may inhibit or block access to information. Regimes of appropriability may even involve subjective aspects, such as the relationship of trust between individuals in organizations. Liao, Welsch, and Stoica (2003) argue that trust is the precursor element for resource acquisition and knowledge exchange and combination. According to them, actors who develop a high degree of trust are better able to appropriate the knowledge, information and other forms of resources available on their social network. The opportunistic actions of certain actors in cooperative environments, for example, may make them take more significant benefits, but may also negatively affect group trust (Kim \& Inkpen, 2005). Thus, because information exchange may be positive, competing organizations tend to adopt identical $\mathrm{R} \& \mathrm{D}$ approaches to achieve a high degree of connectivity (Wiethaus, 2005), because the lower the intellectual protection of property rights, the higher the appropriateness of knowledge and the greater incentive to invest in $\mathrm{R} \& \mathrm{D}$. 
- $\mathrm{H}_{3}$ : There is a positive and statistically significant association between regimes of appropriability and general recognize the value.

\subsection{Relationship power}

Relationship power is the intensity by which the organization can influence the inter-organizational relationship network. Even though Cohen and Levinthal (1990) have not highlighted relationship power in their model, for them, as an organization develops a broad and active network of internal and external relationships, individuals' "awareness of others" capabilities and knowledge' will be strengthened. This is to say that the relationship power of an organization is expressed by the need to transfer information from an organization to its environment through its spillovers (Zahra \& George, 2002) or as a result of organizational synergy (Roberts et al., 2012). Naqshbandi and Kaur (2011) define this power as relative capacity (RC), which is the company's ability to control knowledge in front of other companies in the sector. For them, RC is the force that controls the access to available creation and innovation, from which arguments are formulated to verify the fourth hypothesis of this study. Todorova and Durisin (2007) argue that relationship power moderates the construction in the valorization and exploration of new knowledge, since they are relationships that involve the use of energy and other resources to obtain better results. However, its proposed model requires a repositioning of this construct, as its indication is not clear as to whether it is a mediating or moderating variable. Building relationship power consists of relationships within the organization, as well as relationships with customers and other external parties who are interested in the business. Finally, relationship power occurs through synergy between organizations and their partners and has a positive and significant correlation with recognize the value of external knowledge (Roberts et al., 2012).

- $\mathrm{H}_{4}$ : There is a positive and significant association between relationship power and recognize the value.

\section{RESEARCH MODEL}

Figure 3.1 shows the operationalization of the variables presented in the theoretical framework, providing their positions and their hypotheses to be tested. 
The tested model assumes that regimes of appropriability, relationship power, SIM, and the process of recognize the value are direct antecedents of general recognize the value.

(Figure 3.1)

SEARCH MODEL TO PREDICTORS OF RECOGNIZE THE VALUE

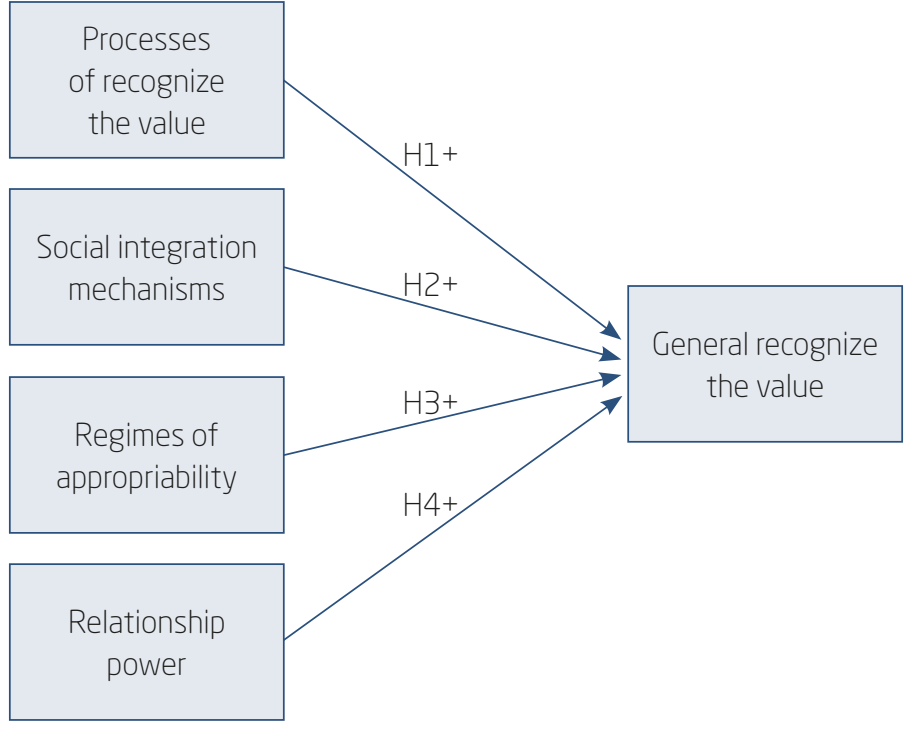

Source: Elaborated by the authors.

\section{METHODOLOGY}

The research was conducted through a quantitative, explanatory study (Hair Jr., Babin, Money, \& Samouel, 2005). The sample is considered nonprobabilistic and is composed of 283 individuals whose data are presented in Figure 4.1. Questionnaires were distributed on paper and also by electronic means. The process lasted about three weeks, and the return rate was $35 \%$. The data obtained in the research were treated according to the guidelines of Hair Jr. et al. (2005, p. 261).

The technique adopted is quantitative, through Partial Least Square Structural Equations (MEE-PLS), using the SmartPLS 2.0 software, as this technique is less demanding in terms of the distributions usually found in surveys, which rarely meet multivariate normality. Additionally, confidence intervals were determined by applying the technique of 500 bootstrapping resamplings. 


\section{(Figure 4.1)}

\section{SAMPLE DEMOGRAPHIC DATA}

\begin{tabular}{|c|c|c|c|c|c|}
\hline $\begin{array}{l}\text { How many years have you } \\
\text { been working at this company? }\end{array}$ & $\begin{array}{l}n=75 \\
26 \%=1 \text { year }\end{array}$ & $\begin{array}{l}n=80 \\
28 \%=2 \text { years }\end{array}$ & $\begin{array}{l}n=113 \\
40 \% 3 \Leftrightarrow 5\end{array}$ & $\begin{array}{l}n=15 \\
5 \% 6 \Leftrightarrow 9\end{array}$ & \\
\hline $\begin{array}{l}\text { In which hierarchical level is } \\
\text { your job? }\end{array}$ & $\begin{array}{l}n=141 \\
50 \% \text { Low }\end{array}$ & $\begin{array}{l}n=105 \\
37 \% \text { Midle }\end{array}$ & $\begin{array}{l}n=37 \\
13 \% \text { High }\end{array}$ & & \\
\hline $\begin{array}{l}\text { Is your company public or } \\
\text { private? }\end{array}$ & $\begin{array}{l}n=260 \\
92 \% \text { Private }\end{array}$ & $\begin{array}{l}n=23 \\
8 \% \text { Public }\end{array}$ & & & \\
\hline How many employees? & $\begin{array}{l}n=57 \\
20 \%<20\end{array}$ & $\begin{array}{l}n=65 \\
23 \% 21 \Leftrightarrow 200\end{array}$ & $\begin{array}{l}n=37 \\
13 \% 201 \Leftrightarrow 500\end{array}$ & $\begin{array}{l}n=124 \\
44 \%>500\end{array}$ & \\
\hline What is the company field? & $\begin{array}{l}n=99 \\
35 \% \text { Industry }\end{array}$ & $\begin{array}{l}n=60 \\
21 \% \text { Commerce }\end{array}$ & $\begin{array}{l}n=124 \\
44 \% \text { Services }\end{array}$ & & \\
\hline $\begin{array}{l}\text { Is your company more } \\
\text { innovative than its } \\
\text { competitors? }\end{array}$ & $\begin{array}{l}n=113 \\
39 \% \text { Yes }\end{array}$ & $\begin{array}{l}n=61 \\
21 \% \text { No }\end{array}$ & $\begin{array}{l}n=109 \\
38 \% \text { Same }\end{array}$ & & \\
\hline Age & $\begin{array}{l}n=108 \\
39 \% 17 \Leftrightarrow 21\end{array}$ & $\begin{array}{l}n=65 \\
23 \% 22 \Leftrightarrow 26\end{array}$ & $\begin{array}{l}n=35 \\
12 \% 27 \Leftrightarrow 31\end{array}$ & $\begin{array}{l}n=18 \\
6 \% 32 \Leftrightarrow 36\end{array}$ & $\begin{array}{l}n=57 \\
20 \%>37\end{array}$ \\
\hline Gender & $\begin{array}{l}n=123 \\
43 \% \text { Male }\end{array}$ & $\begin{array}{l}n=160 \\
57 \% \text { Female }\end{array}$ & & & \\
\hline
\end{tabular}

$n=283$.

Source: Elaborated by the authors.

\section{RESULTS AND ANALYSIS}

Figure 5.1 presents the results of the convergent validity of the models tested, as well as the discriminant validity and reliability of internal consistency, followed by the total effects. Convergent validity confirms that the scale corresponds to other measures of the concept (Hair Jr. et al., 2005). Its criterion is the value of average variance extracted (AVE), which is the average variance extracted. It must be greater than 0.5 for each latent variable in the model. The result obtained was high, i.e., above 0.5 (Chin, 2001), for each data collection instrument used (Figure 5.2.). This result shows that the indicators (questionnaire variables) that measure the latent variables Soc_Integ (0.77), Power (0.75), RecV_Proc (0.62), RecVal (0.67), and RegAp (0.67), respectively, converge to the same latent variable and, in fact, measure what they intend to measure.

Discriminant validity ensures how much the measured concepts are considered sufficiently unmistakable (Hair Jr. et al., 2005). The discriminant 
validity of the model was developed by the criterion of Fornell and Larcker (1981), in which the square root of the AVE must be higher than the intercorrelations between the other constructs. It is observed by the arrangement presented in Figure 5.1, that the diagonal values (AVE square root) are higher than the other intercorrelations, both row, and column. This analysis demonstrates that the latent variables investigated should not be confused with each other.

\section{(Figure 5.1)}

RELIABILITY TEST, DISCRIMINANT, AND CONVERGENT VALIDITY; DESCRIPTIVE STATISTICS OF THE MODEL

\begin{tabular}{|c|c|c|c|c|c|}
\hline Latent variable & 1 & 2 & 3 & 4 & 5 \\
\hline 1. Soc_Integ & 0.88 & & & & \\
\hline 2. Power & 0.14 & 0.87 & & & \\
\hline 3. RecV_Proc & 0.37 & 0.16 & 0.79 & & \\
\hline 4. Rec_Val & 0.44 & 0.22 & 0.55 & 0.82 & \\
\hline 5. RegAp & 0.12 & 0.16 & 0.14 & 0.27 & 0.82 \\
\hline AVE & 0.77 & 0.75 & 0.62 & 0.67 & 0.67 \\
\hline Compound validity & 0.94 & 0.94 & 0.89 & 0.89 & 0.91 \\
\hline $\mathrm{R}^{2}$ & & & & & 0.40 \\
\hline Cronbach's Alpha & 0.93 & 0.92 & 0.84 & 0.84 & 0.88 \\
\hline Median & 3.51 & 3.32 & 3.25 & 3.19 & 3.17 \\
\hline Average & 4.00 & 3.00 & 3.00 & 3.00 & 3.00 \\
\hline Standard deviation & 1.17 & 1.08 & 1.01 & 1.05 & 1.16 \\
\hline Coef. of variation & $33 \%$ & $33 \%$ & $31 \%$ & $33 \%$ & $37 \%$ \\
\hline
\end{tabular}

Soc_Integ: social integration mechanisms; power: relationship power; RecV_Proc: processes of recognize the value; Rec_Val: general recognize the value; RegAp: regimes of appropriability.

\section{Source: Elaborated by the authors}

The reliability of internal consistency was obtained by Cronbach's alpha, whose generally accepted lower limit is 0.7 , but may decrease to 0.60 in exploratory research (Hair Jr., Black, Babin, Anderson, \& Tatham, 2009, p. 126). This value indicates that all questions of each variable converge in the direction of measuring the construct for which they are intended. Parameters of Hair Jr. et al. (2005) confirm the internal consistency as a measure that 
evaluates the reliability and solidity between the constructs of multiple variables. Indicators of each construct should measure and match the construct with which they are related. This value is considered sufficient for searches when it is above 0.8. As shown in Figure 5.2, the values found are all satisfactory, that is, Soc_Integ (0.93), Power (0.92), RecV_Proc (0.84), RecVal (0.84) and RegAp (0.88).

The reliability of the model is measured by the factor loadings of each indicator, which must be greater than 0.7 (Fornell \& Larcker, 1981). According to the analyzes, the indicator loads presented values above 0.7 , without exception.

Tests were performed to verify the possibility of multicollinearity that would compromise the model analysis. Five regression models were performed, one for each group of indicators of each latent variable over one indicator of another variable. Variance inflation factor (VIF) values are in all cases below 3.5, as indicated by Hair Jr. et al. (2009) and shown in Figure 5.2.

\section{(Figure 5.2)}

VALUES OF VIF TO INVESTIGATION MODEL VARIANTS

\begin{tabular}{llllllllll}
\hline \multicolumn{2}{c}{ RecVal_Pro } & \multicolumn{2}{c}{ RecVal_Ger } & \multicolumn{2}{c}{ SIM } & \multicolumn{2}{c}{ RegApr } & \multicolumn{2}{c}{ PoRel } \\
\hline RecVal_Pro_1 & 1.90 & RecVal_Ger_1 & 1.72 & SIM_3 & 3.22 & RegAp_2 & 2.20 & PoderRel_5 & 2.21 \\
\hline RecVal_Pro_2 & 1.83 & RecVal_Ger_3 & 1.98 & SIM_4 & 3.01 & RegAp_3 & 2.51 & PoderRel_7 & 2.78 \\
\hline RecVal_Pro_3 & 1.67 & RecVal_Ger_4 & 1.88 & SIM_5 & 3.43 & RegAp_4 & 2.07 & PoderRel_8 & 3.06 \\
\hline RecVal_Pro_4 & 1.79 & RecVal_Ger_5 & 1.81 & SIM_6 & 2.75 & RegAp_6 & 2.26 & PoderRel_9 & 2.45 \\
\hline RecVal_Pro_5 & 1.72 & & & SIM_7 & 2.56 & RegAp_7 & 1.84 & PoderRel_10 & 3.22 \\
\hline
\end{tabular}

RecVal_Pro: processes of recognize the value; RecVal_Ger: general recognize the value; SIM: social integration mechanisms; RegApr: regimes of appropriability; PoRel: power of relationship.

Source: Elaborated by the authors.

The quality of the model was confirmed by Pearson's coefficient of determination (R2), with values of $\mathrm{R} 2=26 \%$ for the social and behavioral sciences, being considered as a large effect (Cohen, 1988). By assessing the value obtained for R2, the investigated model is capable of explaining about $40 \%$ (40.2) of the recognize the value, which, as set forth, represents the overall ability by which the company identifies external, new, or available information for indoor application. Respectively, by the path analysis, the magnitude of the effects was obtained by the value of Beta. This explanation can be seen from the positive association that occurs between the variables 
shown in Figure 5.3 in relation to recognize the value, that is, Soc_Integ (0.248; $\mathrm{p}<0.001)$; Power (0.092; $\mathrm{p}<0.05)$; RecV_Proc (0.417; $\mathrm{p}<0.001)$; and RegAp (0.169; $\mathrm{p}<0.001)$.

\section{(Figure 5.3)}

\section{PARTIAL LEAST SQUARES (PLS) WITH STATISTICAL SIGNIFICANCE AND PREDICTIVE POWER}

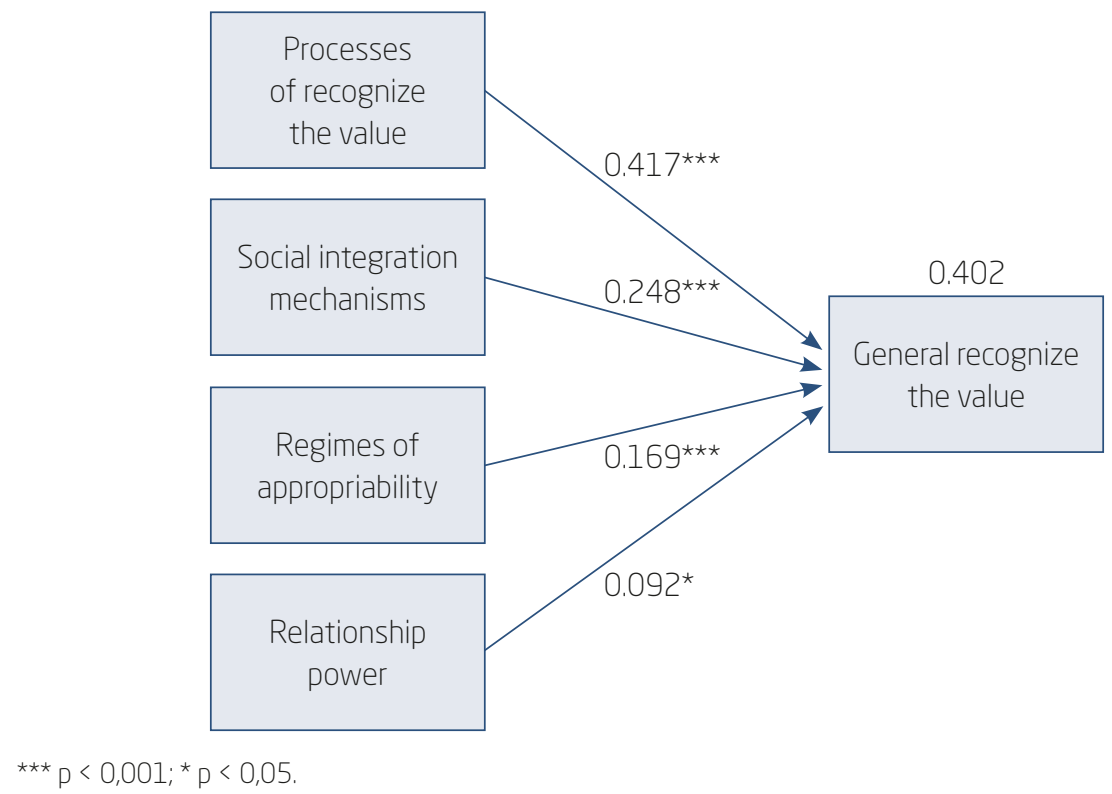

Source: Elaborated by the authors.

Figure 5.4 shows the Student $t$ values obtained with bootstrapping analysis for factor loadings and standardized coefficients (betas). Regarding path analysis, the highest value found for the relationship between RecV_Proc and RecVal_ger (0.417) stands out, as this is the most influential association of the model. In the sequence, Soc_Integ and RegAp have values of 0.248 and 0.169, respectively, in relation to RecVal_Ger. PoRel has RecVal_Ger association value of 0.092 . These values mean that, for each unit that varies the predictor variable, there will be simultaneous variation in the dependent variable. Thus, the most significant explanation for RecVal_Ger variability is the one with the highest beta value and the highest predictive power of recognize the value, i.e., RecVal_Proc. This finding of the study reinforces the development of the scales presented by noting that similar results were found by Filenga (2015) when investigating the predictor constructs of 
RecVal_Ger, but focusing on the individual. Confirmation of this finding, therefore, suggests that organizations wishing to gain greater recognize the value capability from their employees should endeavor to get work processes to capture valuable external information, new or otherwise, to bring to the company. Routines, procedures, computer programs, organizational culture, and the entire systematization of tasks indicate a significant ability to provide $\mathrm{AC}$ to the organization.

\section{(Figure 5.4)}

STATISTICAL SIGNIFICANCE OF THE MODEL

\begin{tabular}{lccccccc}
\hline Relation & $\begin{array}{c}\text { Original } \\
\text { sample (0) }\end{array}$ & $\begin{array}{c}\text { Sample } \\
\text { mean (M) }\end{array}$ & $\begin{array}{c}\text { Standard } \\
\text { deviation } \\
\text { (STDEV) }\end{array}$ & $\begin{array}{c}\text { Standard } \\
\text { error } \\
\text { (STERR) }\end{array}$ & $\begin{array}{c}\text { T Statistics } \\
\text { (|O/STERRI) }\end{array}$ & p Value \\
\hline Soc_Integ -> Rec_Val & 0.25 & 0.25 & 0.05 & 0.05 & 4.58 & 0.0000 \\
\hline Power -> Rec_Val & 0.09 & 0.09 & 0.04 & 0.04 & 2.08 & 0.0373 \\
\hline RecV_Proc - > Rec_Val & 0.42 & 0.42 & 0.06 & 0.06 & 7.32 & 0.0000 \\
\hline RegAp -> Rec_Val & 0.17 & 0.17 & 0.05 & 0.05 & 3.47 & 0.0005 \\
\hline
\end{tabular}

RecV_Proc: processes of recognize the value; Soc_Integ: social integration mechanisms; RegAp: regimes of appropriability; power: power of relationship; Rec_Val: general recognize the value.

Efforts should also be directed towards offering SIM in obtaining AC. The same is valid for directing efforts to empower such employees with regimes of appropriability that represent barriers to external knowledge important to the organization. Employees need to be aware of the barriers that control the level of difficulty an organization faces externally to capture valuable information, that is, recognize the value of valuable information depends on how far those limits imposed by those with valuable information are exceeded.

The same reasoning applies to the organization's relationship power, that is, knowing and making appropriate use of the organization's power in obtaining essential external knowledge favors recognize the value. Finally, finding that recognize the value is a result of actions that can be taken by the organization itself and encourages the development of actions related to the constructs addressed.

Model fit quality indicators are based on relevance or predictive validity (Q2) or Stone-Geisser indicator. This indicator assesses how close the model is to what was expected of it. It is known that a perfect model would have 
Q2 = 1 and would show that the model reflects reality without errors (Ringle, Silva, \& Bido, 2014). To measure the effect that an independent variable has on another dependent, we used the Cohen indicator (f2), both presented in Figure 5.5 and based on Hair Jr., Hult, Ringle, and Sarstedt (2014), in which $0.02,0.15$, and 0.35 are considered small, medium and large, respectively. Note that the effect size of the ratio RecV_Proc and Rec_Val is between medium and close to large $(\mathrm{Q} 2=0.1344)$ and $(\mathrm{f} 2=0.2458)$. For the Soc Integ and RecVal relationship, a small and close to medium effect (Q2 = $0.0494)$ and $(f 2=0.0870)$ were obtained. For the RegAp and Rec_Val relationship, the values are Q2 $=0.0261$ and $\mathrm{f} 2=0.0452$, therefore both closer to small effect. Finally, the relationship between Power and Rec_Val presented values $(\mathrm{Q} 2=0.0082)$ and $(\mathrm{f} 2=0.0134)$, thus, small. In summary, it is noted that these results are consistent with those previously presented about the importance of RecVal_Proc as a predictive power of Rec_Val.

(Figure 5.5)

QUALITY INDICATORS OF THE MODEL

\begin{tabular}{lll}
\hline \multicolumn{1}{c}{ Latent variable } & $(\mathrm{Q} 2)$ & $(\mathrm{f} 2)$ \\
\hline RecV_Proc - > Rec_Val & 0.1344 & 0.2458 \\
\hline Soc_Integ - > Rec_Val & 0.0494 & 0.0870 \\
\hline RegAp - > Rec_Val & 0.0261 & 0.0452 \\
\hline Power - > Rec_Val & 0.0082 & 0.0134 \\
\hline
\end{tabular}

RecV_Proc: processes of recognize the value; Soc_Integ: social integration mechanisms; RegAp: regimes of appropriability; Power: power of relationship; Rec_Val: general recognize the value.

Source: Elaborated by the authors.

Regarding the predictive relevance of the model (Q2), a value of 0.271 was obtained by calculating blindfolding in the SmartPLS software (CV Red: 0.271 ). This value means how close the model is to what is expected, that is, its ability to represent reality. According to Hair Jr. et al. (2014), the value must be greater than zero.

\section{DISCUSSION}

Recognize the value is a construct that addresses the ability to identify the value of information that is external to the organization, whether new or 
available, and that can be harnessed within the internal environment. Recognizing the value of external information is the initial step and, therefore, fundamental for the occurrence of both individual and organizational AC. This study aimed to update the concept of recognize the value, and other constructs of the model tested, and operationalize it in the form of variance for the individual level.

Although the literature review indicates that recognize the value, SIM, regimes of appropriability, and relationship power are moderating variables of AC, this study found that their most appropriate positioning is as predictors, given their high predictive power. This finding corroborates the fundamental postulates of Cohen and Levinthal (1990), but differs from the studies by Zahra and George (2002), Todorova and Durisin (2007) and resulting studies (Huang, Chen, Zhang, \& Ye, 2018; Park, Suh, \& Yang, 2007; Schmidt, 2005). It even differs from more recent studies aimed at demonstrating that AC should be part of management tools (Yildiz et al., 2018).

This study has shown what would be the possible consequences of these findings. Investments in R\&D explain recognize the value, but not only regimes of appropriability, SIM, relationship power, and especially labor processes, as well. This aspect redirects efforts beyond R\&D in obtaining AC, i.e., the creation of a more complex and non-simplified and exclusive R\&D system is necessary. In short, efforts should be included related to the predictor variables indicated here.

This more complex proposition about the explanation and occurrence of AC finds theoretical support in studies by Flatten et al. (2011) and Gomez and Vargas (2009), who call for multidimensional or broader models such as Resource-Based View (Jiménez-Barrionuevo, García-Morales, \& Molina, 2011). It also rests on the prerogative that innovation occurs when knowledge about unmet customer needs intersects with knowledge about technology solutions, that is, at the intersection of unmet needs with the potential of the organization. Both types of knowledge, which can be classified as tacit and explicit, about such needs, are located outside the enterprise and need to be absorbed for innovation to occur, which is, in short, the relationship between recognize the value, specifically, and AC (Schweisfurth \& Raasch, 2018). However, precisely because this knowledge is outside the organization, the problem of geographical distance as a limitation to innovation persists, as being outside does not necessarily mean being in the reach of the organization that wants it, as stated by Presutti, Boari, Maiocchi and Molina-Morale (2019), especially when the knowledge is not only about the unmet needs of the customer, but also about how the technological solutions, 
combined with those already available, configure the whole necessary for the formation of AC.

The finding that SIM as the second-largest predictive power of Recognize the value provides theoretical support for stating that the effects of external knowledge on individuals' ability to innovate depend on their positions in the internal social structure, i.e., organizations. They need to manage such mechanisms in order to foster acceptance, and they need acceptance in order to break the inertia of interaction between individuals. According to Tortoriello (2015), the positive effects of external knowledge on innovation generation become more positive when individuals who acquire external knowledge overcome existing gaps in the internal knowledge-sharing network. Therefore, it is up to the manager to adopt mechanisms for social integration, identify such failures and remedy them, so that they are not an impediment to individuals in the search for external knowledge that may be brought to the internal environment.

\section{CONCLUSION}

The present study achieved its general objective by identifying the antecedent variables of the construct of recognize the value, and testing them empirically, which allowed explaining around $40 \%$ of their variability through the processes of recognize the value themselves, as well as the SIM, by the relationship power, and by regimes of appropriability. The findings indicate that the institutionalization of work routines, in concert with the other variables of the study, gives the organization significant portions of progress in achieving the critical capacity of recognize the value.

In managerial terms, the results can be interpreted as a recommendation to understand the organization composed of "dynamic capacity", as proposed by Zahra and George (2002) and not only as having "knowledge stocks", as initially suggested by Cohen and Levinthal (1990). Additionally, variables that influence recognize the value can be managed by managers interested in enhancing this ability. Work processes represent the instrumentalization that channels the efforts to capture innovation in order to introduce it into the operations of the organization.

Like any research, it is not free of limitations. First, non-probabilistic sampling brings with it the limitation of generalizing the conclusions, since statistical inference is conceptually impaired. However, surveys conducted at the organizational level suffer from additional difficulties regarding data collection, respondents' resistance to providing corporate data, and the 
multiplicity of sectors that are sampled. Nevertheless, multiple studies have been conducted with these same limitations, and the commonly used approach has been to limit the generalizability to the proper contexts of the sample. In addition, limitations have been observed when surveys employ a single privileged informant rather than using secondary organizational data. Such an approach, however, would not be feasible in the context of this research because it involves construct items that are not available as secondary data.

Future studies may be conducted to improve the scales employed to potentially explain a more significant portion of variance, as well as to identify additional elements that may complement this explanation. Additionally, one can seek to decompose the processes of recognize the value, the most powerful construct in the model, in order to understand how much capacity can be improved.

\section{ANTECEDENTES DO RECONHECIMENTO DE VALOR NA CAPACIDADE ABSORTIVA}

\section{RESUMO}

Objetivo: A capacidade dos indivíduos em reconhecer o valor de uma informação externa e aplicá-la à empresa é fundamental para a capacidade absortiva organizacional. Este estudo objetivou definir e operacionalizar o construto reconhecimento de valor e identificar seus antecedentes e poderes preditivos.

Originalidade/valor: Analisou como esse construto ocorre no nível do indivíduo, dos grupos de trabalho e dos processos, além de indicar sua relação com os demais preditores presentes na literatura, cujas bases teóricas podem ser classificadas pelas vertentes de Cohen e Levinthal (1990) e Zahra e George (2002). A primeira considera capacidade absortiva como estoque de conhecimento, e a segunda, como capacidade dinâmica.

Design/Metodologia/abordagem: Adotou-se o método de Modelagens de Equações Estruturais para testar o modelo de variância, com quatro preditores sobre o reconhecimento de valor de modo geral. A amostra não probabilística é formada por 283 indivíduos que responderam ao questionário eletrônico. 
Resultados: Os resultados foram satisfatórios, pois o modelo apresentou poder de $40 \%$ de explicação sobre como ocorre o reconhecimento de valor, e o nível dos processos de trabalho foi o construto com maior poder preditivo $(\beta=0,417)$, o que significa que, se houver variação na capacidade de reconhecimento de valor dos processos, ocorrerá também a variação do reconhecimento de valor de modo geral, ou seja, os processos de trabalhos propiciam reconhecer o valor de uma informação nova. As demais hipóteses também foram suportadas, porém com efeitos comparativamente menores. O estudo limita-se à identificação e análise dos preditores e não contempla seus consequentes, cuja abordagem sugere-se.

\section{PALAVRAS-CHAVE}

Capacidade absortiva. Reconhecimento de valor. Mecanismos de integração social. Regimes de apropriação. Poder dos relacionamentos.

\section{REFERENCES}

Antonello, C. S. (2007). O processo de aprendizagem entre níveis individual, grupal e organizacional e organizacional: Desenvolvimento de competências. Organizações em Contexto, 3(5), 223-250.

Bolívar-Ramos, M. T., García-Morales, V. J., \& Martín-Rojas, R. (2013). The effects of information technology on absorptive capacity and organisational performance. Technology Analysis \& Strategic Management, 25(8), 905-922. doi:10.1080/09537325.2013.823152

Bosch, F. A. J. van den, Volberda, H. W., \& Boer, M. de (1999). Coevolution of firm absorptive capacity and knowledge environment: Organizational forms and combinative capabilities. Organization Science, 10(5), 551-568.

Bosch, F. A. J. van den, Wijk, R. van, \& Volberda, H. W. (2003). Absorptive capacity: Antecedents, models, and outcomes. In M. Easterby-Smith \& M. A. Lyles (Eds.). The Blackwell handbook of organizational learning and knowledge management (pp. 278-301). Oxford, UK: Blackwell.

Camerer, C., \& Vepsalainen, A. (1988). The economic efficiency of corporate culture. Strategic Management Journal, 9, 115-126. 
Camisón, C., \& Forés, B. (2010). Knowledge absorptive capacity: New insights for its conceptualization and measurement. Journal of Business Research, 63, 707-715

Chin, W. W. (2001). PLS-Graph User's Guide, Version 3.0. [S. 1.]: Soft Modeling.

Cockburn, I. M., \& Henderson, R. M. (1998). Absorptive capacity, coauthoring behavior, and the organization of research in drug discovery. Journal of Industrial Economics, 46(2), 157-183.

Cohen, J. (1998). Statistical power analysis for the behavioral sciences (2nd ed.). New York: Psychology Press.

Cohen, W., \& Levinthal, D. (1989). Innovation and learning: The two faces of R\&D. Economic Journal, 99(397), 569-596.

Cohen, W., \& Levinthal, D. (1990). Absorptive capacity: A new perspective on learning and innovation. Administrative Science Quarterly, 35(2), 128-152.

Daghfous, A. (2004). Absorptive capacity and the implementation of knowledge-intensive best practices. Advanced Management Journal, 69(2), 21-27.

Duchek, S. (2013). Capturing absorptive capacity: A critical review and future prospects. Schmalenbach Business Review, 65, 312-329.

Engelman, R. M., Fracasso, E. M., Schmidt, S., \& Zen, A. C. (2017). Intellectual capital, absorptive capacity and product innovation. Management Decision, 55(3), 474-490

Filenga, D. (2015). Detalhando o reconhecimento de valor na capacidade absortiva: Antecedentes, consequentes e proposta de operacionalização em modelo de variância (Tese de doutorado, Fundação Getulio Vargas).

Flatten, T. C., Engelen, A., Zahra, S. A., \& Brettel, M. A. (2011). Measure of absorptive capacity: Scale development and validation. European Management Journal, 29, 98-116.

Fornell, C., \& Larcker, D. F. (1981). Structural Equation Models with unobservable variables and measurement error: Algebra and statistics. Journal of Marketing Research, 18(3), 382-388.

Gomez, J., \& Vargas, P. (2009). The effect of financial constraints, absorptive capacity and complementarities on the adoption of multiple process technologies. Research Policy, 38, 106-119.

Hair Jr., J. F., Babin, B., Money, A. H., \& Samouel, P. (2005). Fundamentos de métodos de pesquisa em administração. Porto Alegre: Bookman.

Hair Jr., J. F., Black, W. C, Babin, B., Anderson, R. E., \& Tatham, R. L. (2009). Análise multivariada de dados (6a ed.). Porto Alegre: Bookman 
Hair Jr., J. F., Hult, T. M., Ringle, C. M., \& Sarstedt, M. A. (2014). Primer on Partial Least Squares Structural Equation Modeling (PLS-SEM). Los Angeles: Sage.

Harrington, S. J., \& Guimaraes, T. (2005). Corporate culture, absorptive capacity and IT success. Information and Organization, 15, 39-63.

Hotho, J. J., Becker-Ritterspach, F., \& Saka-Helmhout, A. (2012). Enriching absorptive capacity through. Social Interaction. British Journal of Management, 23, 383-401.

Huang, D., Chen, S., Zhang, G., \& Ye, J. (2018). Organizational forgetting, absorptive capacity, and innovation performance. Management Decision, 56(1), 87-104.

Jiménez-Barrionuevo, M. M., García-Morales, V. J., \& Molina, L. M. (2011). Validation of an instrument to measure absorptive capacity. Technovation, 31, 190-202.

Kim, C., \& Inkpen, A. C. (2005). Cross-border R\&D alliances, absorptive capacity and technology learning. Journal of International Management, 11, 313-329.

Lane, P. J., Koka, B. R., \& Pathak, S. (2006). The reification of absorptive capacity: A critical review and rejuvenation of the construct. Academy of Management Review, 31 (4), 833-863.

Lane, P. J., \& Lubatkin, M. (1998). Relative absorptive capacity and interorganizational learning. Strategic Management Journal, 19, 461-477.

Liao J., Welsch, H., \& Stoica, M. (2003). Organizational absorptive capacity and responsiveness: An empirical investigation of growth-oriented SMEs. Entrep Theory Pract, 28(1), 63-86.

Liyanage, S., \& Barnard, R. (2003). Valuing of firms' prior knowledge: A measure of knowledge distance. Knowledge and Process Management, 10(2), 85-98.

Magni, M., Paolino, C., Cappetta, R., \& Proserpio, L. (2013). Diving too deep: how cognitive absorption and group learning behavior affect individual learning. Academy of Management Learning \& Education, 12 (1), 51-69. doi:10.5465/amle.2011.0096

Martinez-Noya, A., Garcia-Canal, E., \& Guillen, M. F. (2013). R\&D outsourcing and the effectiveness of intangible investments: Is proprietary core knowledge walking out of the door? Journal of Management Studies, 50(1), 67-91. doi:10.1111/j.1467-6486.2012.01086.x

Nahapiet, J., \& Ghoshal, S. (1998). Social capital, intellectual capital, and the organizational advantage. Academy of Management Review, 23, 242-266. 
Naqshbandi, M. M., \& Kaur, S. (2011). Relative capacity. Dimensions and open innovation. Journal of Management Research, 11 (2), 77-86.

Nonaka, I., \& Takeuchi, H. (1995). The knowledge-creating company. Oxford: Oxford University Press.

Park, J., Suh, H., \& Yang, H. (2007). Perceived absorptive capacity of individual users in performance of Enterprise Resource Planning (ERP) usage: The case for Korean firms. Information \& Management, 44, 300-312.

Popadiuk, S. (2012). Scale for classifying organizations as explorers, exploiters or ambidextrous. International Journal of Information Management, 32, 75-87.

Presutti, M., Boari, C., Majocchi, A., \& Molina-Morale, X. (2019). Distance to customers, absorptive capacity, and innovation in high-tech firms: The dark face of geographical proximity. Journal of Small Business Management, 57(2), 343-361.

Ringle, C. M., Silva, D., \& Bido, D. S. (2014). Modelagem de equações estruturais com utilização do SmartPLS. Revista Brasileira de Marketing, 13(2), 54-71.

Roberts, N., Galluch, P. S., Dinger, M., \& Grover, V. (2012). Absorptive capacity and information systems research: Review, synthesis, and directions for future research. MIS Quarterly, 36(2), 625-648.

Schleimer, S. C., \& Pedersen, T. (2013). The driving forces of subsidiary absorptive capacity. Journal of Management Studies, 50(4), 646-672. doi:10.11 11/joms. 12010

Schmidt, T. (2005). Absorptive capacity: One size fits all? Firm-level analysis of absorptive capacity for different kinds of knowledge [Paper n. 05-72]. ZEW. Recuperado de http://hdl.handle.net/10419/24168.

Schweisfurth, T. G., \& Raasch, C. (2018). Absorptive capacity for need knowledge: Antecedents and effects for employee innovativeness. Research Policy, 47(4), 687-699.

Teece, D. J. (1986). Profiting from technological innovation: Implications for integration, collaboration, licensing and public policy. Research Policy, 15, 285-305.

Todorova, G., \& Durisin, B. (2007). Absorptive capacity: Valuing a reconceptualization. Academy of Management Review, 32 (3), 774-786.

Tortoriello, M. (2015). The social underpinnings of absorptive capacity: The moderating effects of structural holes on innovation generation based on external knowledge. Strategic Management Journal, 36, 586-597. 
Vega-Jurado, J., Gutiérrez-Gracia, A., \& Fernández-de-Lucio, I. (2008). Analyzing the determinants of firm's absorptive capacity: Beyond R\&D. R\&D Management, 38(4), 392-405.

Wiethaus, L. (2005). Absorptive capacity and connectedness: Why competing firms also adopt identical R\&D approaches. International Journal of Industrial Organization, 23(5-6), 467-481.

Yam, C. M., Guan, J. C., Pun, K. F., \& Tam, P. Y. (2004). An audit of technological innovation capabilities in Chinese firms: Some empirical findings in Beijing, China. Research Policy, 33(8), 1123-1250.

Yildiz, H. E., Fey, C. F., \& Zhou, A. J. (2018). Fostering integration through HRM practices: An empirical examination of absorptive capacity and knowledge transfer in cross-border M\&As. Journal of World Business, 55(2), 100947.

Zahra, S., \& George, G. (2002). Absorptive capacity: A review, reconceptualization, and extension. Academy of Management Review, 27(2), 185-203.

\section{AUTHOR NOTES}

Douglas Filenga, Ph.D. from the School of Business Administration of São Paulo (Eaesp), Getulio Vargas Foundation (FGV); Otávio P. Sanchez, Ph.D. from the School of Business Administration of São Paulo (Eaesp), Getulio Vargas Foundation (FGV).

Douglas Filenga is now professor of Technical and Technological Education (EBTT) at the Federal Institute of Education, Science and Technology of São Paulo (IFSP); Otávio P. Sanchez is now associate professor at the School of Administration of São Paulo (Eaesp) of Getulio Vargas Foundation (FGV).

Correspondence concerning this article should be addressed to Douglas Filenga, Avenida Mogi das Cruzes, 1.501, Parque Suzano, Suzano, São Paulo, Brazil, CEP 08673-010.

E-mail: filenga@ifsp.edu.br

EDITORIAL BOARD

Editor-in-chief

Gilberto Perez

Associated Editor

Glória Charão Ferreira

Technical Support

Vitória Batista Santos Silva

\section{EDITORIAL PRODUCTION}

Publishing Coordination

Jéssica Dametta

Layout Designer

Emap

Editorial Intern

Paula Di Sessa Vavlis

Graphic Designer

Libro
Language Editor

Daniel de Almeida Leão 